\title{
The Effects of Competence and Motivation on Performance Mediated by Organization Commitment
} (Case Study Indonesian Government Agencies)

\author{
Rhian Indradewa, Stefano Randi \\ Esa Unggul University, Jl. Arjuna Utara 9, Kebon Jeruk, Jakarta, Indonesia
}

Corresponding Author: Rhian Indradewa

\begin{abstract}
Performance improvement in the context of government agencies is very important. There are several factors that can affect employee's performance. These factors serve to ascertain whether the performance will be increased or decreased by involving these factors in performance appraisals. The aim of this study is to analyze the effect of competence and motivation on performance mediated by organization commitment. The population used in this study were employees in Indonesian government agencies. The respondents were 186 of Ministry of Home Affairs employees. The sampling technique used was the Convenience Sampling method. The analytical model used in this study was descriptive and Structural Equation Modeling analysis with LISREL Program. It is concluded that commitment of organization contributes to employee's performance and is influenced by both, the employee's competence and motivation, whereas the competence and the motivation do not give any effect to their performance.
\end{abstract}

Keywords: Competence, Motivation, Organization Commitment, Performance.

\section{INTRODUCTION}

\subsection{Research Background}

Growth in all fields gave rise to demands regarding to the need for more professional, skilled, open and serviceoriented Civil Servants to the public. Civil Servants are required to be able to complete their duties and responsibilities effectively and efficiently. An organization can be said to be developed or developed if the organization has qualified employees. The leader of the organization or agency can foster employee's performance by using managerial strategies (Indradewa, 2016).

Generally, the benefits of performance management are to maximize profits, motivate employees to be higher, and be able to control management for the better (Wibowo, 2013). Improving the performance of the government apparatus is one of the development strategies for a country in carrying out its state process. Zaim, et al. (2013) analyzed the relationship between individual competences and individual performance, the study shows that there was a positive relationship between competence and individual performance. The results of the study by Zaim, et al. (2013) provide some empirical evidence regarding to the effects of individual competences on organization performance. Another factor that can affect performance is motivation. Motivation is considered as a strength that strengthens a person's behavior, gives a picture in behavior, and triggers a person's tendency to do something (Farhad, Ghatari and Hasiri, 2010). In research conducted by Dalluay and Jalagat (2016) proves that motivation and performance have a relationship of interdependence which is not linear but in two-ways, integration of the relationship of individual motivation and performance. 
Another factor is organization commitment. Organization commitment arises gradually in the personal of employee. Broadly speaking, organization commitment is to take steps to improve workers' feelings about their work so that these workers will become more committed to the organization where they work (Allen and Meyer, 2013). Tsui, Lin and Yu (2013) conducted research on the relationship between organization commitment and performance. One of the results of this research is that organization commitment can affect employee's performance both in the long term and short term.

\subsection{Research Objective and Questions}

From the description above, the researcher notices that competence and motivation are two substantial variables that have a very strong influence on the growth of organization commitment which in turn, helps to boost employee's performance towards a stronger and positive direction. The reason is because there are elements contained in competence and motivation that are closely related to the influence of organization commitment. So, the effect of increasing organization commitment will have an impact on improving employee's performance. Organizations or instances need to carry out several processes so that organization competence, motivation and commitment can move simultaneously and sustainably, and employee's performance as well as organization or agency performance can also be consistently increased.

Based on the background of the problem and previous studies, the problems going to be discussed in the current study are formulated as follows:

1) To what extent competence affects performance?

2) To what extent motivation affects performance?

3) To what extent organization commitment mediates competence and motivation on performance?

Based on the background and the problems of the current study, therefore the purposes of the current study are formulated as follows:

1) Investigating the effect of competence on performance mediated by organization commitment

2) Investigating the effect of motivation on performance mediated by organization commitment

\section{LITERATURE REVIEW \\ 2.1 Competency}

Byars and Rue (2008) define the competence of a trait or characteristic required by a position holder to be able to carry out a position well, or it can also mean the characteristics / characteristics of a person that are easily seen including the knowledge, skills and behavior that make it possible to work. Competence according to Spencer and Spencer (2008) is a characteristic that stands out to someone and becomes ways of behaving and thinking in all situations and lasts for a long period of time. Spencer and Spencer (2008) explain that there are four competence indicators, namely trait, self concept, knowledge and skill. According to Zwell (2008) there are several factors that can affect one's competence, namely beliefs, skills, experience, personality characteristics, emotional issues, intellectual abilities, and culture of the organization.

\subsection{Motivation}

Motivation according to Steers (2011) is the strength of the tendency of an individual to get involved in activities that aims at work. This is not a feeling of pleasure related to the results of various jobs as it is satisfaction, but rather a feeling of being willing / willingness to work to achieve the goals of the job. Atkinson, et al. (2010), motivation is explained as a person's tendency to act, increase and produce one or more effects. The definition of motivation according to Chaplin (2011) is an interim variable that is used to cause certain factors in arousing, managing, maintaining, and channeling behavior towards a goal. Factors that influence an employee's motivation to 
work according to Sunyoto (2013) are several, namely promotion, work performance, responsibility, respect, recognition of abilities and expertise, success.

\subsection{Organization Commitment}

According to Steers (2011) organization commitment as a sense of identification (trust in organization values), involvement (willingness to do their best for the sake of the organization), and loyalty (the desire to remain a member of the organization concerned) expressed by an employee of his company. According to Luthans (2013) organization commitment is often defined as a strong desire which is not only to remain a member of a particular organization and to urge business at a high level on behalf of the organization, but also to define confidence and acceptance of organization values and goals, which also as asserted by Mathis and Jackson (2012) that the degree to which employees believe, accept organization goals, will remain or will not leave the organization define what organization commitment is. In a similar line, organization commitment according to Velnampy (2013) is an internalization of organization values and goals, a willingness to work hard on behalf of the organization and a strong desire to stay with the organization. Furthermore, Robbins and Judge (2013) define organization commitment as a condition in which an employee sides with a particular organization and the employee's goals and desires to maintain membership in the organization.

\subsection{Performance}

According to Armstrong and Baron (2009), performance is a result of work that has a strong relationship with the goals of organization strategy, customer satisfaction and economic contribution. While Harsuko (2011) asserts that performance is the extent to which a person has played for him in carrying out organization strategies, both in achieving specific goals related to the role of individuals and / or by showing competences that are otherwise relevant to the organization. Performance is basically what employees do or don't do in carrying out their work (Mathis and Jackson, 2012). The factors that influence the performance based on Timpe (2013) consist of internal factors and external factors. Internal factors are factors that are associated with the characteristics of a person. While external factors are factors that affect the performance of someone who comes from the environment.

\section{RESEARCH HYPOTHESES AND MODEL}

\subsection{Research Hypotheses}

Based on the detailed description of the literature review above, the current study proposes several hypotheses as follows:

1) The Effect of Competence on Organization Commitment

Supriyatin, et al (2019) competences and job satisfaction will impact the quality of the job. Basic characteristics of competence are things that can be related to increased performance of individuals or teams (Mathis and Jackson, 2012). As revealed by Steers (2011) organization commitment as a sense of identification (trust in organization values), involvement (willingness to do their best for the sake of the organization, and loyalty (the desire to remain a member of the organization concerned) expressed by an employee. This is in accordance with the research of Katawneh and Osman (2014) which concluded that competence influences organization commitment. Based on the detailed explanation of the previous studies, the current study proposes hypothesis 1 as follows:

(H1): Competence has significant and positive effect on organization commitment.

\section{2) The Effect of Motivation on Organization Commitment}


Motivation conditions influence, generate, direct and maintain behavior related to the work environment (Rivai and Sagala, 2013). Employees who are highly motivated, they will understand what is done, are passionate about working, work happily without any pressure and are able to give the best results (Hasibuan, 2014). Hunt and Morgan (2004) stated that employees who have high organization commitment if, have trust and accept the goals and values of the organization, want to strive towards achieving organization's goals, and have a strong desire to survive as a member of the organization. As in the research of Al-Madi, et al. (2017), employee's working motivation influences three dimensions of organization commitment (affective, sustainable and normative). And Widyaningrum (2011) and Khrisna, et al. (2015) concluded that employee motivation affects organization commitment. Based on the detail explanation of the previous studies, the current study proposes hypothesis 2 as follows:

\section{(H2): Motivation has significant and positive effect on organization commitment.}

\section{3) The Effect of Organization \\ Commitment on Performance}

According to Mar'at (2000), commitment on performance is influenced by several factors such as motivation, compensation, training, leader functions, the climate of cooperation, work spirit, and conflicts that occur in an office. Committed employees reflect the loyal nature of the organization by giving effort, ideas, so that their performance improves. This performance improvement is able to facilitate the organization in achieving its goals. This supports the research of Ghorbanpour, et al. (2014) that organization commitment influences employee performance in the accountant community. Akhtar, et al. (2015) and Yamali (2018) whose research results were influences of organization commitment on employee performance. Based on the detail explanation of the previous studies, the current study proposes hypothesis 3 as follows:

(H3): Organization commitment has significant and positive effect on performance.

\section{4) The Effect of Competence on Performance}

Competence is a basic characteristic of someone that indicates how to think, behave, act and draw conclusions that can be done and maintained by someone at a certain period of time (Moeheriono, 2012). Khaerudin, et al. (2018) pointed out that there is a direct influence of employee competence on the performance of Ministry of Finance employees of the Ministry of Finance. Yamali (2018) said that competence influences employee's performance. Based on the detailed explanation of the previous studies, the current study proposes the hypothesis 4 as follows:

\section{(H4): Competence has significant and positive effect on performance.}

\section{5) The Effect of Motivation on Performance}

According to Robbins and Judge (2013), motivation processes explain the intensity, direction and perseverance of an individual to achieve goals. This is supported by the results of research of Muhamud, et al. (2017) that employee's motivation is a driver of high levels of employee's performance at the Hormuud Company in Mogadishu Somalia. Olusadum and Anulika (2018) concluded that employee's motivation improves employee's performance. Based on the detailed explanation on the previous studies, the current study proposes the hypothesis 5 as follows:

(H5): Motivation has significant and positive effect on performance. 


\subsection{Research Model}

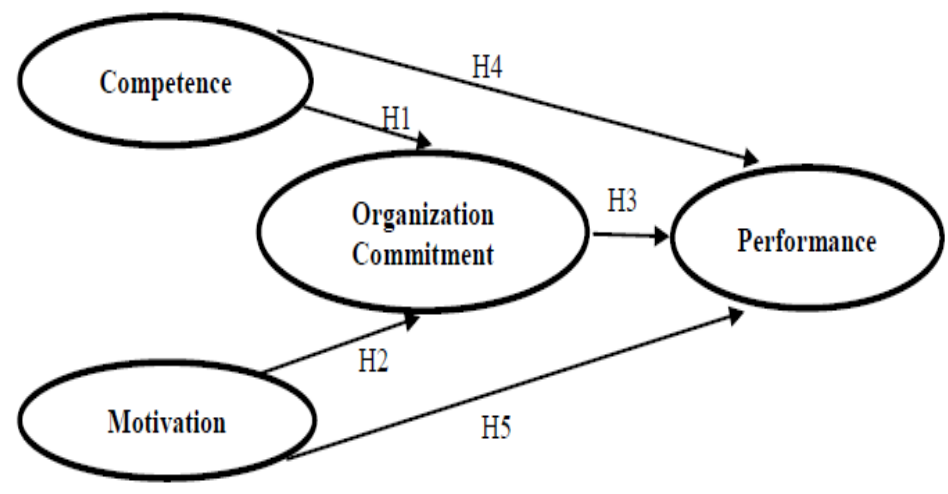

Figure 1. Conceptual Study Model Framework

\section{METHODOLOGY}

The design of the current study is an explanatory research. By applying this type of research, the current study will verify the causal relationship between competence and motivation as the independent variables, organization commitment as the mediating variable, and performance as the dependent variable. The current study also applies correlational research, which examines whether the two variables are correlated to each other or not, and to investigate the strength and the purpose of the correlation. The current study applies Structural Equation Model (SEM) analysis method using LISREL to investigate the significant rate and the correlation between the variables.

The populations used in this study are employees in Indonesian government agencies. Respondents employed were 186 of Ministry of Home Affairs employees. The sampling technique used was the Convenience Sampling method. The measurement of these variables was adapted from the questionnaire instrument which applies Likert scale in five ordered level responses from 1 to 5 ( 1 is "totally disagree" and 5 is "totally agree"). The operational definition and the detail of the measurement of each variable are displayed in the table 1 below.

Table 1. Operational Definition of Variables

\begin{tabular}{|c|c|c|c|}
\hline No & Variable & Dimensions & Indicators \\
\hline \multirow[t]{9}{*}{1} & \multirow{9}{*}{$\begin{array}{l}\text { Competence } \\
\text { (Spencer and Spencer, 1993) }\end{array}$} & \multirow[t]{3}{*}{ Characters } & Inisiative \\
\hline & & & Team Work \\
\hline & & & Development \\
\hline & & \multirow[t]{2}{*}{ Self Concept } & Self Confidence \\
\hline & & & Self Control \\
\hline & & \multirow[t]{2}{*}{ Knowledge } & Information Updating \\
\hline & & & Skills \\
\hline & & \multirow[t]{2}{*}{ Thinking } & Analytics Thinking \\
\hline & & & Conceptual Thinking \\
\hline \multirow[t]{12}{*}{2} & \multirow{12}{*}{$\begin{array}{l}\text { Motivation } \\
\text { (Herzberg, 1959) }\end{array}$} & \multirow[t]{5}{*}{ Motivation Factor } & Achievement \\
\hline & & & Recognition \\
\hline & & & Job / Duty \\
\hline & & & Progress \\
\hline & & & Responsibility \\
\hline & & \multirow[t]{7}{*}{ Hygiene Factor } & Policy \\
\hline & & & Supervision \\
\hline & & & Benefits \\
\hline & & & Environment \\
\hline & & & Position \\
\hline & & & Working Condition \\
\hline & & & Job Secure \\
\hline \multirow[t]{3}{*}{3} & \multirow[t]{3}{*}{ Organization Commitment (Allen and Meyer, 2013) } & Affective Commitment & Pride \\
\hline & & Continuance Commitment & Sacrifice \\
\hline & & Normative Commitment & Loyalty \\
\hline
\end{tabular}


Rhian Indradewa et.al. The effects of competence and motivation on performance mediated by organization commitment (case study Indonesian Government Agencies).

\begin{tabular}{|l|l|l|l|}
\hline 4 & Performance (Mathis and Jackson, 2012) & \multirow{2}{*}{ Job Quality } & Working Standard \\
\cline { 3 - 4 } & & Minimize Error \\
\cline { 3 - 4 } & \multirow{2}{*}{ Job Quantity } & Ability to Complete Main Job \\
\cline { 3 - 4 } & & Ability to Complete Additional Job \\
\cline { 3 - 4 } & Ontime & Ability to Complete Job Ontime \\
\cline { 3 - 4 } & & Ability to Presence Ontime \\
\cline { 3 - 4 } & Team Work & Cooperative Attitude \\
\hline
\end{tabular}

\section{RESULT}

The results of the study concluded that competence influences organization commitment, motivation influences organization commitment, organization commitment influences performance, competence does not affect performance and motivation influences performance.

\section{1) Normality and Outlier Tests}

In order to test the normal distribution of the data for the analysis, the researcher applied skewness value statistical test provided in SPSS 23 software program. Assumptions for normality of data is fulfilled when the critical value (c.r.) is less than \pm 2.58 (Hair et al., 2008). Normality test is managed by applying assessment of normality. Based on univariate test, the value in c.r. column (skewness) is less than \pm 2.58 . Therefore, it is proven that the data is normally distributed.

Outlier test is a test to confirm that the data being analyzed have similar range. The current study found that the Chi Square values Table with DF 13 and $\alpha=0,001$ is 34.5. Based on the calculation, none of the observation has p-value $<0.001$. In addition, the Mahalanobis d-squared value reaches 33.730, less than $(<) 34.5$ (X2 table). It indicates that there is no outlier.

Table 2. The Result of Validity and Construct Reliability

\begin{tabular}{|c|c|c|c|c|c|c|c|c|c|}
\hline \multirow[b]{2}{*}{ Variabel } & \multirow[t]{2}{*}{ Standard Loading } & \multirow[b]{2}{*}{ Error } & \multicolumn{4}{|c|}{ Construct Reliability } & \multicolumn{3}{|c|}{ Variance Extracted } \\
\hline & & & $\begin{array}{l}S T d . \\
\text { Loading }\end{array}$ & $\begin{array}{l}\left(\sum \text { STd. }\right. \\
\text { Loading) }^{2}\end{array}$ & $\sum_{\text {Error }}$ & $\begin{array}{l}\text { Nilai } \\
\text { CR }\end{array}$ & $\begin{array}{l}\text { Standard } \\
\text { Loading }^{2}\end{array}$ & $\begin{array}{l}\sum_{\text {Loading })^{2}} \\
{ }^{2} \text { Std. }\end{array}$ & $\begin{array}{l}\text { Nilai } \\
\text { VE }\end{array}$ \\
\hline \multicolumn{10}{|c|}{ Competency (COM) } \\
\hline Com1 & 0,75 & 0,44 & \multirow{7}{*}{5,03} & \multirow{7}{*}{25,30} & \multirow{7}{*}{3,4} & \multirow{7}{*}{$\mathbf{0 , 8 8}$} & 0,56 & \multirow{7}{*}{3,59} & \multirow{7}{*}{$\mathbf{0 , 5 1}$} \\
\hline Com2 & 0,67 & 0,56 & & & & & 0,44 & & \\
\hline Com3 & 0,75 & 0,44 & & & & & 0,56 & & \\
\hline Com4 & 0,73 & 0,47 & & & & & 0,53 & & \\
\hline Com5 & 0,71 & 0,50 & & & & & 0,50 & & \\
\hline Com7 & 0,71 & 0,49 & & & & & 0,50 & & \\
\hline Com8 & 0,71 & 0,50 & & & & & 0,50 & & \\
\hline \multicolumn{10}{|c|}{ Motivation (MO) } \\
\hline Mo1 & 0,93 & 0,13 & \multirow[t]{2}{*}{1,84} & \multirow[t]{2}{*}{3,38} & \multirow[t]{2}{*}{0,3} & \multirow[t]{2}{*}{0,91} & 0,86 & \multirow[t]{2}{*}{1,68} & \multirow[t]{2}{*}{$\mathbf{0 , 8 4}$} \\
\hline Mo2 & 0,91 & 0,17 & & & & & 0,82 & & \\
\hline \multicolumn{10}{|c|}{ Organization Commitment (KO) } \\
\hline KO1 & 0,73 & 0,46 & \multirow{8}{*}{6,16} & \multirow{8}{*}{37,94} & \multirow{8}{*}{3,22} & \multirow{8}{*}{$\mathbf{0 , 9 2}$} & 0,53 & \multirow{8}{*}{4,72} & \multirow{8}{*}{$\mathbf{0 , 5 9}$} \\
\hline $\mathrm{KO} 2$ & 0,74 & 0,46 & & & & & 0,54 & & \\
\hline $\mathrm{KO} 3$ & 0,73 & 0,46 & & & & & 0,53 & & \\
\hline $\mathrm{KO} 4$ & 0,84 & 0,30 & & & & & 0,70 & & \\
\hline KO5 & 0,76 & 0,42 & & & & & 0,57 & & \\
\hline KO6 & 0,80 & 0,35 & & & & & 0,64 & & \\
\hline KO7 & 0,73 & 0,46 & & & & & 0,53 & & \\
\hline KO8 & 0,83 & 0,31 & & & & & 0,68 & & \\
\hline \multicolumn{10}{|c|}{ Performance (KI) } \\
\hline Ki1 & 0,80 & 0,30 & \multirow{10}{*}{8,5} & & & & 0,64 & & \\
\hline $\mathrm{Ki} 2$ & 0,75 & 0,45 & & & & & 0,56 & & \\
\hline Ki3 & 0,76 & 0,43 & & & & & 0,57 & & \\
\hline $\mathrm{Ki} 4$ & 0,88 & 0,23 & & & & & 0,77 & & \\
\hline Ki5 & 0,85 & 0,28 & & & & & 0,72 & & \\
\hline Ki6 & 0,90 & 0,19 & & 72,25 & 2,67 & $\mathbf{0 , 9 6}$ & 0,81 & 7,23 & $\mathbf{0 , 7 3}$ \\
\hline Ki7 & 0,90 & 0,10 & & & & & 0,81 & & \\
\hline Ki8 & 0,89 & 0,26 & & & & & 0,79 & & \\
\hline Ki9 & 0,88 & 0,23 & & & & & 0,77 & & \\
\hline Ki10 & 0,89 & 0,20 & & & & & 0,79 & & \\
\hline
\end{tabular}


Rhian Indradewa et.al. The effects of competence and motivation on performance mediated by organization commitment (case study Indonesian Government Agencies).

\section{2) Validity and Reliability Tests}

LISREL software program also provides the user to test the validity with loading standard $(\lambda)$ more than (>) 0.5 and asserted as reliable when the Construct Reliability is more than (>) 0.7 .

\section{3) Goodness-of-Fit Test}

In the current study, the goodnessof-fit test was processed by using LISREL software. The table 3 below shows the result of the goodness-of-fit index after the test was conducted:

Table 3. Goodness-of-Fit Index

\begin{tabular}{|c|c|c|c|}
\hline Group & Indicator & Value & Result \\
\hline \multirow[t]{4}{*}{1} & Degree of Freedom & 286 & \multirow{4}{*}{ Good fit } \\
\hline & Chi Square & 442,74 & \\
\hline & $\mathrm{NCP}$ & 151,53 & \\
\hline & Confidence Interval & 99,$02 ; 212,00$ & \\
\hline \multirow[t]{3}{*}{2} & RMSEA & 0,054 & \multirow{3}{*}{ Good fit } \\
\hline & Confidence Interval & 0,$043 ; 0,063$ & \\
\hline & P Value & 0,28 & \\
\hline \multirow[t]{4}{*}{3} & ECVI Model & 3,36 & \multirow{4}{*}{ Good fit } \\
\hline & ECVI Saturated & 4,09 & \\
\hline & ECVI Independence & 127,67 & \\
\hline & Confidence Interval & 3,$08 ; 3,69$ & \\
\hline \multirow[t]{6}{*}{4} & AIC Model & 621,53 & \multirow{6}{*}{ Good fit } \\
\hline & AIC Saturated & 756,00 & \\
\hline & AIC Independence & 23618,63 & \\
\hline & CAIC Model & 1010,30 & \\
\hline & CAIC Saturated & 2353,33 & \\
\hline & CAIC Independence & 23732,23 & \\
\hline \multirow[t]{6}{*}{5} & NFI & 0,98 & \multirow{6}{*}{ Good fit } \\
\hline & CFI & 0,99 & \\
\hline & NNFI & 0,99 & \\
\hline & IFI & 0,99 & \\
\hline & RFI & 0,98 & \\
\hline & PNFI & 0,80 & \\
\hline 6 & Critical N & 144,98 & Marginal fit \\
\hline \multirow[t]{3}{*}{7} & GFI & 0,85 & \multirow{3}{*}{ Marginal fit } \\
\hline & AGFI & 0,80 & \\
\hline & PGFI & 0,64 & \\
\hline
\end{tabular}

\section{4) Hypothesis Test}

The results shown by the LISREL software describe the correlation links between the variables, competence, motivation, organization commitment and performance. The links is depicted in the image below:

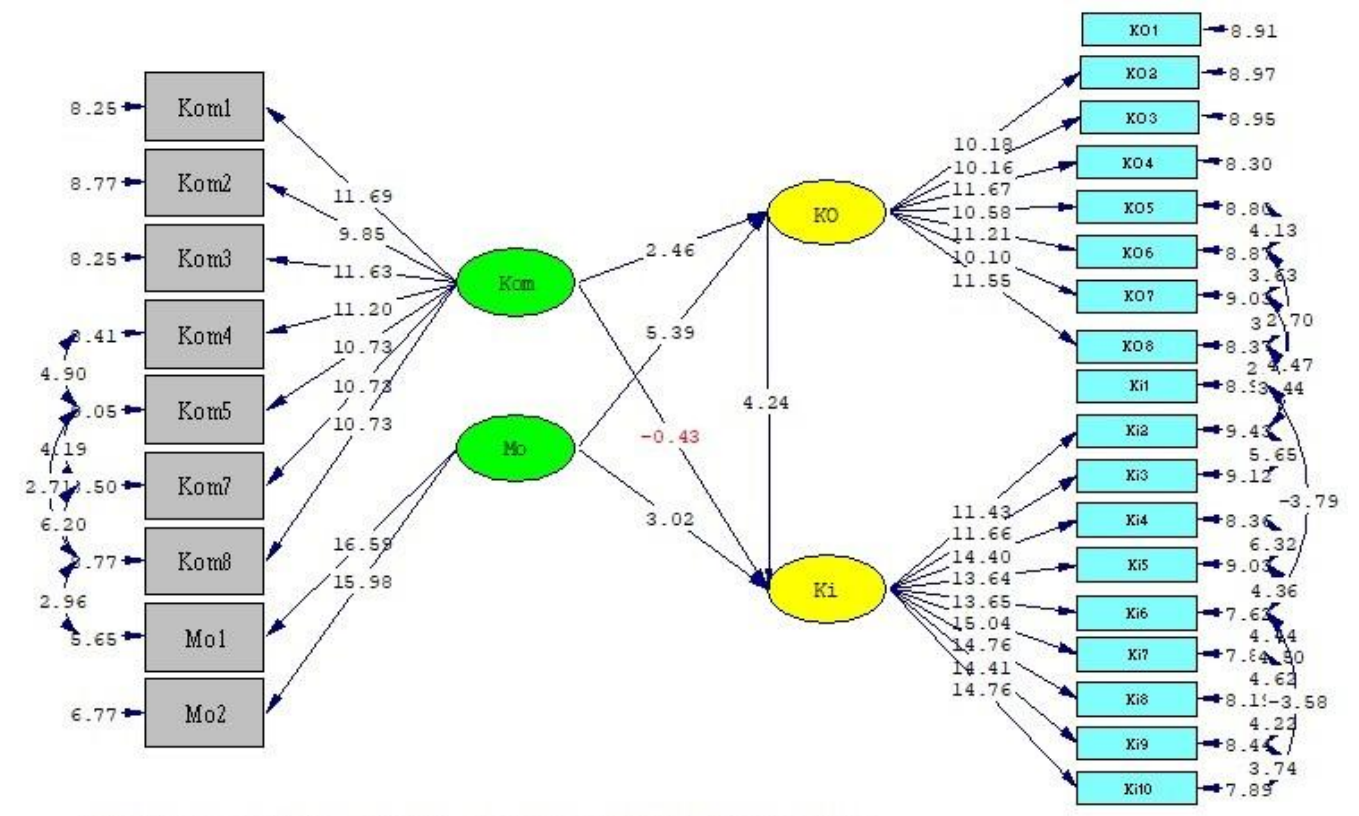

Chi-Square $=437.53, \mathrm{df}=286, \mathrm{P}-\mathrm{value}=0.00000, \mathrm{RMSEA}=0.054$ 
Rhian Indradewa et.al. The effects of competence and motivation on performance mediated by organization commitment (case study Indonesian Government Agencies).

Figure 2. The result of SEM model analysis
Tabel 4. The Result of Hypothesis Test
\begin{tabular}{|l|l|l|l|}
\hline Hypotheses & Correlation between Variables & T value & Additional Information \\
\hline H1 & Competence $\rightarrow$ Organization Commitment & 2,46 & Significant \\
\hline H2 & Motivation $\rightarrow$ Organization Commitment & 5,39 & Significant \\
\hline H3 & Organization Commitment $\rightarrow$ Performance & 4,24 & Significant \\
\hline H4 & Competence $\rightarrow$ Performance & $-0,43$ & Not Significant \\
\hline H5 & Motivation $\rightarrow$ Performance & 3,02 & Significant \\
\hline \multicolumn{4}{|c|}{ Source: Data processed by LISREL software, 2019} \\
\hline
\end{tabular}

\section{a. First Hypothesis Test}

The first hypothesis test states that (H1): Competence has significant and positive effect on Organization Commitment. The table 4 above shows that the competence variable is proven to have significant and positive effect on the organization commitment, which is shown by the T-value at 2.46 above 1.96 (> 1.96).

\section{b. Second Hypothesis Test}

The second hypothesis test states that (H2): Motivation has significant and positive effect on Organization Commitment. The table 4 above shows that the competence variable is proven to have significant and positive effect on the organization commitment, which is shown by the T-value at 5.39 above 1.96 (> 1.96).

\section{c. Third Hypothesis Test}

The third hypothesis test states that (H3): Organization Commitment has significant and positive effect on
Performance. The table 4 above shows that the competence variable is proven to have significant and positive effect on the organization commitment, which is shown by the T-value at 4.24 above 1.96 (> 1.96).

\section{d. Fourth Hypothesis Test}

The fourth hypothesis test states that (H4): Competence has no significant and positive effect on Performance. The table 4 above shows that the competence variable is not proven to have significant and positive effect on the performance, which is shown by the T-value at -0.43 below 1.96 (> 1.96).

\section{e. Fifth Hypothesis Test}

The fifth hypothesis test states that (H5): Motivation has significant and positive effect on Performance. The table 4 above shows that the motivation variable is proven to have significant and positive effect on the performance, which is shown by the T-value at 3.02 above 1.96 (> 1.96).

Table 5. The Indirect Effect (Mediating Effect)

\begin{tabular}{|l|l|}
\hline The Pattern of The Correlation & The Weight of Indirect Effect \\
\hline Competence $\rightarrow$ Organization Commitment $\rightarrow$ Performance & 0.118 \\
\hline Motivation $\rightarrow$ Organization Commitment $\rightarrow$ Performance & 0.168 \\
\hline \multicolumn{2}{|c|}{ Source : processed primary data, 2019}
\end{tabular}

Table 5 tells us that the competence affects the performance indirectly through the organization commitment as the mediating variable, with the weight of the indirect effect at 0.118 or $11.8 \%$. Therefore, the better the competence managed by Ministry of Home Affairs employees, the more the organization commitment will increase. Accordingly, it is expected to increase the performance as well.

Table 5 tells us also that the motivation affects the performance indirectly through the organization commitment as the mediating variable, with the weight of the indirect effect at 0.168 or $16.8 \%$. Therefore, the better the motivation managed by Ministry of Home Affairs employees, the more the organization commitment will increase. Accordingly, it is expected to increase the performance as well. 


\section{DISCUSSIONS, CONCLUSIONS \& RECOMMENDATIONS \\ 6.1 DISCUSSIONS \\ 1) The Effect of the Competence on the Organization Commitment}

In the results of testing the first hypothesis, it was found that the results of the analysis supported the $\mathrm{H} 1$ hypothesis that the appropriate competence would increase organization commitment. This means that competence affects organization commitment on Ministry of Home Affairs employees. Competence is a person's ability to carry out tasks in a job. Commitment given by an employee is loyalty shown by the desire to remain in his position or job. In this study the competence of employees in accordance with the job or task can increase the commitment of an employee at the Ministry of Home Affairs. Appropriate competences in Ministry of Home Affairs employees related to their knowledge and skills, the competences in question are technical expertise, analytical thinking and conceptual thinking. This is in accordance with Yamali (2018); Katawneh and Osman (2014) which states that there is an effect of competence on organization commitment. Employees who have a good competence will be good enough in the high workload. Workload will affect the quality performance (Hapsari, et al., 2019).

\section{2) The Effect of the Motivation on the Organization Commitment}

In the results of testing the second hypothesis, found the results of the analysis support the $\mathrm{H} 2$ hypothesis that high motivation will increase organization commitment. This means that motivation affects the organization commitment of Ministry of Home Affairs employees. Motivation as an employee's tendency to do increased to produce one or more results, or in other words employee motivation is needed to expect to get something better. High commitment given by an employee, especially Ministry of Home Affairs employees because it is caused by the high motivation obtained by the employee.
According to this study high motivation will increase organization commitment and in line with Widyaningrum (2011) that the influence of motivation and culture on organization commitment and employee performance. Khrisna, et al. (2015); AlMadi, et al. (2017) which states that there is an influence of employee motivation on organization commitment.

\section{3) The Effect of the Organization} Commitment on the Performance

In the results of testing the three hypotheses, it was found that the analysis supported the $\mathrm{H} 3$ hypothesis, namely high organization commitment that would improve employee performance. This means that high organization commitment will improve the performance of Ministry of Home Affairs employees. Organization commitment is a strong desire from an employee to remain a member of the organization, and an employee's desire to push for high-level endeavors on behalf of the organization, and the employee's confidence to accept the values and goals of the organization. The organization commitment given by employees to institutions is quite high so that it can improve the performance of these employees because the majority of Ministry of Home Affairs employees realize that if they resign then many things will be disrupted in their lives. This study is in line with Ghorbanpour, et al. (2014) states that there is an effect of organization commitment on audit performance in the accountant community. And Akhtar, et al. (2015) and Yamali (2018) that there is an influence of organization commitment on employee performance.

\section{4) The Effect of the Competence on the Performance}

In the results of testing the fourth hypothesis, it was found that the analysis did not support the hypothesis $\mathrm{H} 4$, that is, the appropriate competence did not improve employee performance. This means that competence does not affect the performance 
of Ministry of Home Affairs employees. This is in line with the results of research by Jeffrey and Febrianti (2018) that competence has no effect on the performance of employees of the Indonesian Motor Association. Competence does not affect employee performance because, at the Indonesian Motor Association, there are still some employees in certain positions that are not supported by education according to the type of work, therefore the application of competence in an office has not been carried out optimally. The workers feel that they are already competent but actually they do not have the motivation to do something well so that they tend not to work optimally.

Competence is an ability and characteristic possessed by a civil servant in the form of knowledge, skills, and behavioral attitudes required in the implementation of his job duties, so that the employees can carry out his duties professionally, effectively, efficiently. Placement of the right position in a position becomes the absolute and most important thing in an agency or organization since an employee can develop themselves and innovate in a job. In this fourth hypothesis, the competences already possessed by the Ministry of Home Affairs employees are appropriate but cannot improve the employee's performance because they lack of motivation because the positions are not in accordance with their interests. This hypothesis is not in line with Khaerudin, et al. (2018) states that there is an effect of placement and competence on performance through employee commitment at the Indonesian Ministry of Defense's Financial Office. And it is also not in line with Yamali (2018) that competence affects the performance of construction service company experts in Jambi Province.

\section{5) The Effect of the Motivation on the Performance}

In the results of testing the hypothesis five, it was found that the analysis supported the H5 hypothesis, namely high motivation would improve employee's performance. This means that motivation affects the performance of the Ministry of Home Affairs employees. Motivation is something that gives strength to encourage individual to behave in achieving goals. Motivation is also interpreted as an internal driving force that causes people to do something or try to meet their needs. Giving full responsibility of the institution to employees in a job is also felt sufficient, so that employees feel comfortable and more responsible in completing the work. The most important motivation provided by this institution is that the Ministry of Home Affairs provides various opportunities for all employees to develop the potential abilities. This hypothesis is also in line with Muhamud, et al. (2017) suggest that employee motivation influences the high level of employee performance at Hormuud Company in Mogadishu Somalia. In line with Widyaningrum (2011); Ulusadum and Anulika (2018) significantly proved that motivation influences employee performance.

\section{6) The Effect of the Organization Commitment as Mediating Variables} Ministry of Home Affairs seen motivation has a direct effect on organization commitment, with a value of $t$ $=5.39$ (> 1.96). On motivation directly affects employee performance, with a value of $t=3.02(>1.96)$ and on organization commitment directly affects performance, with a value of $t=4.24$ (>1.96). So it can be concluded that organization commitment is able to mediate the relationship of motivation to the performance of Ministry of Home Affairs employees.

The second result is organization commitment mediating between competences and the performance of Ministry of Home Affairs employees. In Figure 2 (Path Diagram T-Value) shows competence directly affects organization commitment, with a value of $\mathrm{t}=2.46$ (> 1.96), organization commitment on performance has a direct effect, with a value 
of $\mathrm{t}=4.24(1,96)$ while competency on performance has no direct effect, with a value of $\mathrm{t}=-0.43(<1.96)$. It can be concluded that competences affect employee's performance through organization commitment, but competence does not directly influence the performance of Ministry of Home Affairs employees. This is commonly called a partial mediation analysis because it can affect directly or indirectly (Hair, et al., 2011).

\subsection{CONCLUSIONS}

The conclusions of the current study based on the result analysis are described as follows:

1) There is a significant and positive effect of the competence, as one of the variables, on the organization commitment of Ministry of Home Affairs employees. It indicates that the better of the competence managed by Ministry of Home Affairs the more the organization commtment will increase.

2) There is a significant and positive effect of the motivation, as one of the variables, on the organization commitment of Ministry of Home Affairs employees. It indicates that the better of the motivation managed by Ministry of Home Affairs the more the organization commitment will increase.

3) There is a significant and positive effect of the organization commitment, as one of the variables, on the performance of Ministry of Home Affairs employees. It indicates that the better of the organization commitment managed by Ministry of Home Affairs the more the performance will increase.

4) There is a no significant and positive effect of the competency, as one of the variables, on the performance of Ministry of Home Affairs employees. It indicates that the competency it is not only the variables tha will affect the performance. Even the employees feel that they are very competent, but when they feel that their position it is not appropriate they will not give their best performance. They don't have have a motivation to achieve the best effort that they can perform.

5) There is a significant and positive effect of the motivation, as one of the variables, on the performance of Ministry of Home Affairs employees. It indicates that the better of the motivation managed by Ministry of Home Affairs the more the performance will increase.

\subsection{RECOMMENDATIONS}

Based on the conclusions elicited in the current study, some suggestions are offered for the Ministry of Home Affairs employees:

1) To keep the employee organization commitment that will affect the performance. Ministry of Home Affairs should put employee based on their best fit position to their competence and interest because it will increase their motivation to achieve the best performance.

2) Ministry of Home Affairs should share information to the employees about their job and their carrer path. Therefore, it is recommended that Ministry of Home Affairs opens wider opportunities for its employees to scheduling consultation on any problems faced by their employees. The most highlighted problem here is the way to address the complaints. It is recommended that the company arrange a scheme of all complaints that have been submitted. The purpose of the scheme is to organize the priority list of the problems to be handled first and to offer the best solutions.

\section{REFERENCES}

1. Akhtar, A., Durrani, A.B., and Hassan, W.U. 2015. The Impact of Organization Commitment on Job Satisfaction and Job Performance: An Empirical Study from Pakistan. Journal of Business and Management. Volume 17, Issue 6.Ver. II.

2. Allen and Meyer. 2013. The Measurement and Antecedents of Affective, Continuance and Normative Commitment to 
Organization. Jakarta: PT Elex Media Komputindo.

3. Al-Madi, F.N., Assal, H., Shrafat, F., and Zeglat, D. 2017. The Impact of Employee Motivation on Organization Commitment. European Journal of Business and Management. Vol. 9, No 15.

4. Amstrong, M., and Baron, A. 2009. Performance Management. London: Institute of Personal and Development.

5. Atkinson, L.R., Atkinson, R.C., Smit, E.E., dan Bem, D.J. 2010. Pengantar Psikologi, Jilid II. Tangerang: Interkasara.

6. Byars, L.L., and Rue, L.W. 2008. Human Resource Management, 9th ed. New York: McGraw-Hill.

7. Chaplin, J.P. 2011. Kamus Lengkap Psikologi. Diterjemahkan: Kartini Kartono. Jakarta: PT Radja Grafindo Persada.

8. Dalluay, V. S., and Jalagat, R. C. 2016. Impact of Leadership Style Effectiveness of Managers and Department Heads to Employees Job Satisfaction and Performance on Selected Small-Scale Business in Cavite, Philippines. International Journal of Recent Advances in Organization Behaviour and Decision Sciences. Vo.2 Issue 2 PP $734-751$.

9. Farhad, H. D, Ghatari, A. R and Hasiri, A, (2010). Employees Morale in PublicSector: Is Organization Trust an Important Factor? European Journal of Scientific Research, 46 (3),378-390.

10. Ferdinand, A. 2002. Structural Equation Modelling dalam Penelitian Manajemen. Semarang: FE UNDIP.

11. Ghorbanpour, Z., Dehnavi, H.D., and Heyrani, F. 2014. Examination of Auditor Acceptance of Dysfunctional Behavior Using a Heuristic Model. International Journal of Academic Research in Accounting, Finance and Management Sciences. Vol.4. No.1 pp. 41-51.

12. Hair, J. F., Ringle, C. M., and Sarstedt, M. (2011) 'PLS-SEM: Indeed a silver bullet', Journal of Marketing Theory and Practice, Vol.19, No.1, pp.139-151.

13. Hair, J.F., Anderson, R.E., Tatham, R.L., and Black, W.C. 2008. Multivariate Data Analysis, Fifth Edition. USA: Prentice Hall International.

14. Hapsari, S.M., Iqbal, M. A. and Indradewa, R. (2019) 'The effects of workload and compensation on tax account representative performance mediating by public service level (Case Study of Indonesian Tax Offices)', International Journal of Business Innovation and Research, Vol. 20 No. 1, pp. $47-63$.

15. Harsuko, R. 2011, Mendongkrak Motivasi dan Kinerja: Pendekatan Pemberdayaan SDM. Malang: UB Press.

16. Hasibuan, M. 2014. Manajemen Sumber Daya Manusia. Jakarta: Bumi. Aksara.

17. Herzberg, F. 1959. The Motivation To Work. New York: John Wiley and Sons Inc.

18. Hunt, S.D., and Morgan, R.M. 2004. The Commitment Trust Theory of Relationship Marketing. Journal of Marketing. 58 (3).

19. Indradewa, R., Tjakraatmadja, J.H., and Dhewanto, W. (2016) 'Alliance strategy in $R \& D$ contractual projects for the energy sector: perspective of knowledge and resource-based views', International Journal of Technology Transfer and Commercialization, Vol. 14, No. 1, pp.119.

20. Katawneh A.I., and Osman A. 2014. The Impact of Core Competencies in Improving the Organization Commitment of Employees in Mutah University in Jordan. International Journal of Academic Research in Business and Social Sciences.

21. Khaerudin., Rivai., A., and Riyanto, M. 2018. The Effect Of Placement And Competency On Performance Through Employee Commitment In Financial Center Office Ministry Of Defense Indonesia. Journal of Business and Management. Volume 20, Issue 2. Ver. VIII.

22. Krishna, M., Tresfa, L., and Prasad. R.R. 2015. The Impact of Employee Motivation on Organization Commitmen of Academic Staf of Ambo University Staff. International Journal of Organization Behaviour \& Management Perspectives. Vol.4. No.1.

23. Luthans, F. 2013. Organisional Behavior, Seventh edition. New York: McGrow Hill.

24. Malhotra, N.K., and Birks, D.F. 2012. Marketing Research: An Applied Approach 3rdEuropean Edition. Harlow, England: Prentice-Hall.

25. Mar'at. 2000. Sikap Manusia, Perubahan, serta Pengukurannya. Jakarta: Ghalia.

26. Mathis, R.L. dan Jackson, J.H. 2012. Manajemen Sumber Daya Manusia, Edisi Pertama. Jakarta: Salemba Empat.

27. Moeheriono. 2012. Pengukuran Kinerja Berbasis Kompetensi. Jakarta: Raja. Grafindo Persada. 
28. Muhamud, S.A., Ibrahim, A.A., Hussein, J.M. 2017. The Effect of Motivation on Employee Performance in Hormuud Company in Mogadishu Somalia. International Journal of Development Research. Vol. 07, Issue, 11, pp.1700117008.

29. Rivai, V., dan Sagala, E. 2013. Manajemen Sumber Daya Manusia untuk Perusahaan. Jakarta: Rajawali Pers.

30. Robbins, S.P., and Judge, T.A. 2013. Organization Behavior Edition 15. New Jersey: Pearson Education.

31. Spencer, M.L., and Spencer, M.S. 2008. Competence At Work. Canada: John Wiley \& Son.

32. Steers, R.M. 2011. Efektifitas Organisasi. Jakarta: Erlangga. Sugiyono. 2012. Metode Penelitian Bisnis. Bandung: Alfabeta.

33. Sunyoto, D. 2013. Teori, Kuesioner, dan Analisis Data Sumber Daya Manusia dalam Organisasi Sekolah. Yogyakarta: Multi Presindo.

34. Supriyatin, E., Iqbal, M. A. and Indradewa, R. (2019) 'Analysis of auditor competencies and job satisfaction on tax audit quality moderated by time pressure (Case Study of Indonesian Tax Offices)', International Journal of Business Excellence, Vol. 19 No. 1, pp. $119-136$.

35. Timpe, D. 2013. Seri Manajemen Sumber Daya Manusia Kinerja, Cetakan Kelima. Jakarta: PT Elex Media Komputindo.

36. Tsui, P.L, Lin, Y.S., Yu, T.H. 2013. The Influence of Psychological Contract and Organization Commitment on Hospitality Employee Performance. Social Behavior and Personality. 41. 3.

37. Ulusadum, N,J., and Anulika, N.J. 2018. Impact of Motivation on Employee Performance: A Study of Alvan Ikoku Federal College of Eduaction. Journal of Management and Strategy. Vol. 9, No. 1.

38. Velnampy, T. 2013. Corporate Governance and Firm Performance: A Study of SriLankan Manufacturing Companies. Journal of Economics and Sustainable Development. Vol 4, No3.

39. Wibowo. 2013. Manajemen Kinerja. Jakarta: Rajawali Pers.

40. Widyaningrum, M.E. 2011. Influence of Motivation and Culture on Organization
Commitment and Performence Employee of Medical Services. Academic Research International.

41. Yamali, F.R. 2018. Effect of Compensation, Competencies and Organization Culture on Organization Commitment its Implicationson Experts Performance of Construction Services Company in Jambi Province. International Journal of Advances in Management and Economics. Vol. 7, Issue. 2.

42. Zaim, H., Yasar, M.F., and Unal, Ö. 2013. Analyzing the Effects of Individual Competencies on Performance: A field study in services industries in Turkey. Journal of Global Strategic Management. Vol. 7, No. 2.

43. Zwell, M. 2008. Creating a Culture of Competence. New York: John Wiley and Sons, Inc.

Biographical notes: Rhian Indradewa is a Bachelor of Engineering Faculty at University of Indonesia in 2001, Master of Marketing Management Science in Economic Faculty University of Indonesia in 2005 and Doctoral in School of Business and Management Institut Teknologi Bandung, Indonesia in 2016 specialization in strategic and technology management. $\mathrm{He}$ is a Practitioner and has many experiences in oil, gas and energy sector industry such as PETRONAS (Malaysian oil and Gas Company) and since 2010 joined in PERTAMINA (Indonesian oil and Gas Company). He also becomes a lecturer in ESA UNGGUL University, SBM ITB, BINUS and some Private Universities.

Biographical notes: Stefano Randi was graduated Bachelor Degree from Department of Economic and Management, Esa Unggul University in 2012. During his study at Esa Unggul University, he was actively participating in startup business. In 2019, Stefano Randi earned his Master Degree in Management from Department of Human Resources Management, Esa Unggul University.

How to cite this article: Indradewa R, Randi S. The effects of competence and motivation on performance mediated by organization commitment (case study Indonesian Government Agencies). International Journal of Research and Review. 2021; 8(1): 77-89. 